\title{
Non-performing Loans and Government Taxes in the Albanian Banking System
}

\author{
Ines Nurja \\ Corresponding author: University of New York Tirana, Department of Economics and Finance \\ Kodra e Diellit, Selite, /Tirane, Albania, inesnurja@unyt.edu.al
}

\author{
Andromahi Kufo \\ University of New York Tirana, Department of Economics and Finance \\ Kodra e Diellit, Selite,/Tirane, Albania, andromahikufo@unyt.edu.al
}

\section{Doi:10.5901/mjss.2016.v7n6p129}

\begin{abstract}
Following the financial crisis of 2008, banking institutions all over the world have been reviewing their policies and monitoring the main indicators that might warn a possible default or crisis. One of the most important indicators consistently under control has been the non-performing loans. A lot of efforts to explain the non performing loans factors have taken place in Albania including both macroeconomic and microeconomic factors. This study includes a special reference to the non-performing loans indicator being affected by certain macroeconomic factors, especially by corporate taxes, which has not been studied before. The in-depth analysis considers the following variables: GDP growth rate, the inflation rate, the interest rate and corporate taxes as a dummy variable and includes all banks for a period of 5 years. The study aims to find if there exists any relationship between the NPLs ratio and corporate taxes following the rationale of NPLs being increased as a consequence of tax ratio increased, due to several governmental policies. The results of the regression analysis used, showed up that interest rates have a statistically important impact on non-performing loans. The corporate taxes variable proves to be statistically significant at a level of $90 \%$, which actually gives the possibility for further research in a wider database for a larger time period.
\end{abstract}

Keywords: Non performing loans, GDP growth rate, interest rate, inflation rate, corporate taxes rate.

\section{Introduction}

The Albanian banking system has been under continuous development, new regulation and monitoring from the respective authorities, creating an academic field of studies comparable with international ones in terms of profitability, sustainability and effectiveness. One of the main aspects linked with the above characteristics of the financial system, are non-performing loans. Wherever exists a highly insecure environment, the need of minimizing risks becomes the main interest. And the main risk is that of having money, or liquidity, so that investing will not be a problem. In such a context a non-performing loan is created when payments of interest and/or principal are not performed by the borrower.

The problem of nonperforming loans in Albania has been increasing in the recent years. The accelerated level growth of non-performing loans in the banking system remains a major problem for the economy as well as a main threat. Theoretically, there are many reasons why loans fail to perform. Some of these may include depressed economic conditions, high real interest rate, inflation, lenient terms of credit, high credit growth and risk appetite, and poor monitoring among others.

This paper analyzes the effect of corporate non-performing loans by different macroeconomic variables with a special reference to corporate tax rate. As government regulation increases taxes for corporations, their paying ability becomes less, as they consider an increased obligatory payment that might affect their debt to income ratio, and as such increase the non-performing loan ratio of banks. This implies an indirect effect of government tax policies to nonperforming loans for corporations. Data are collected quarterly from individual banks for a time period of Q4 2008- Q4 2014. This is exactly the time period of non-performing loans increasing due also to the financial crisis effects. The results showed that the non-performing loans ratio is affected by the interest rates variable, which indicates the role of monetary policy on non-performing loans We have a significant effect at a confidence level of $90 \%$ regarding the corporate tax variable. Results indicate the need for further data and research in the field.

In continuance the materials and methodology, as well as the results will be discussed. 


\section{Materials and Methods}

Several authors and researchers all over the world have been studying non-performing loans and factors that affect them form a micro and macroprospective.

Traditionally from the micro prospective, the literature shows some of the following factors affecting non-performing loans: excessive financing from banking institutions (Keeton and Morris, 1987, Saba, 2012), management inefficiencies (Salas and Saurina, 2002), bank size, maturity, credit orientation and credit terms (Rajan and Dhal, 2003), ownership structure, whether this was public or private (Hu et al, 2006), bank-specific factors such as asset growth and quality and operating costs (Bercoff et al, 2002), return on equity and capital adequacy ratio (Vatanvser et al, 2013, Makri et al, 2013).

While regarding the macrofactors: high interest rates (While Sinkey and Greewalt, 1991) can affect the lending situation and non-performing loans, as well as GDP growth (Rajan and Dhal, 2003), credit growth, foreign interest rate and monetary expansion (Bercoff et al, 2002), unemployment rate (Vatanvser et al 2013), inflation rate (Clementina, 2014), exchange rates (De Bock et al, 2012) and public debt (Makri et al, 2013).

The literature has not offered much information regarding the tax rate as a macrofactor affecting non-performing loans.

Albanian banking system has faced the problem of non-performing loans from 2008, just after the crises has evolved. The figure below shows the increasing tendency of non-performing loans for the period 2008-2014, revealing the risk in which the system is exposed and the big challenge that both banks and the regulator has to face.

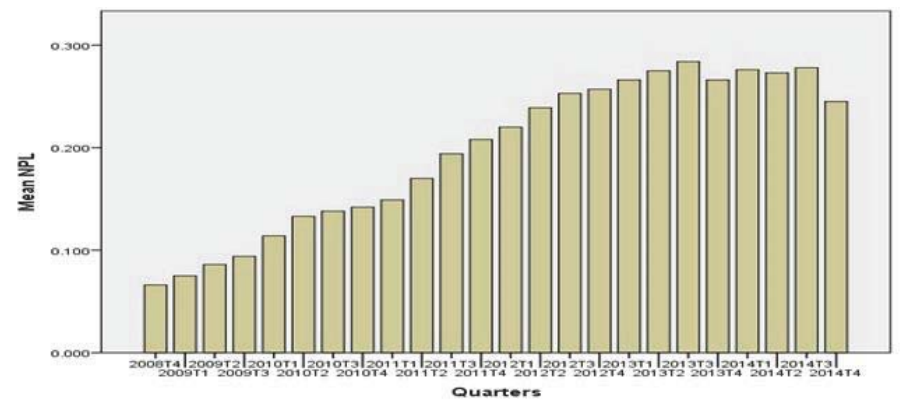

Figure 1. NPLs levels from Q4 2008- Q4 2014, Source: Albanian Association of Banks, own calculations.

As the banking sector has a participation of more than $90 \%$ to the country GDP, any factor that might affect its performance can actually affect the general economic conditions. The same factors divided into macroeconomics and bank-specific ones have been studied also for the non-performing loans, revealling the same factors affecting them as the international literature shows.

This study is mainly concentrated in the macroeconomic factors affecting the non-performing loans, with a special reference to corporate tax rate.

The data used in this study are gathered from different sources and include the period of Q4 2008 - Q4. They iclude as depended variable the non-performing loans rate and indepedent variables the GDP growth rate, the interest rate, the inflation rate and the corporate tax rate. All variables are expressed in decimal numbers, while the corporate tax rate is expressed as a dummy variable,where the value 0 indicates no change and the value 1 indicated the change in the tax level. This variable will illustrate the impact of government tax policies on NPLs

The main research questions of this paper are expressed as following:

1- Is the NPL ratio in Albania explained by GDP growth, interest rates, inflation rates?

2- Is the corporate tax rate variable important to the NPL ratio?

Using the below multiple linear regression:

NPLratio $=\alpha+\beta_{1}{ }^{*}$ GDPgrowth $+\beta_{2}{ }^{*}$ inflationrates $+\beta_{3}{ }^{*}$ interestrates $+\beta_{3}{ }^{*}$ corporatetaxrate $+\mu$

each variable in the model appear as follow:

NPL ration: refers to the non-performing loans as a ratio to total assets of the bank.

GDP growth: refers to economic growth from one period to another expressed as a percentage and adjusted for 
inflation

Inflation rate: is the general level of prices for goods and services expressed as a percentage

Interest rate: is the amount charge by a lender to a borrower for the use of assets, expressed as a percentage of principal.

Corporate tax: is a tax against profit earned by businesses during a given taxable period, expressed as a percentage.

The results and discussion are presented inthe next secion.

\section{Results}

We have first run the correlation of non-performing loans with each of the variables and as per the table below. It is shown that all independent variables have a statistically significant correlation at the level of 0.01 . It is indicated that GDP growth, inflation anf interest rates are negatively correlated with non-performing loans, while corporate tax rate is positively related, as we actually have hypothesized. The strongest relationship is proved to be with interest rates.

Table 1: Spearman Correlations

Correlations

\begin{tabular}{|c|c|c|c|c|c|c|}
\hline & & NPL ratio & GDP $\%$ & INFLATION \% & INTEREST RATES \% & CORPORATE TAX \\
\hline \multirow{3}{*}{ NPL ratio } & Pearson Correlation & 1 & $-.232^{* *}$ & $-.202^{* *}$ & $-.418^{* *}$ & $.211^{* *}$ \\
\hline & Sig. (2-tailed) & & .000 & .000 & .000 & .000 \\
\hline & $\mathrm{N}$ & 352 & 352 & 352 & 352 & 352 \\
\hline
\end{tabular}

**. Correlation is significant at the 0.01 level (2-tailed).

Next we run the multiple regression with the dependent and independent variables. The results are shown in the next table. The high value of Fisher 20.17 shows the importance of the model is high.

Table 2: Analysis of variance

\begin{tabular}{|c|c|c|c|c|c|c|}
\hline \multicolumn{1}{|c|}{ ANOVA $^{\mathrm{a}}$} \\
\hline \multirow{2}{*}{1} & Model & Sum of Squares & Df & Mean Square & F & Sig. \\
\hline & Regression & 1.779 & 4 & .445 & 20.717 & $.000^{\mathrm{b}}$ \\
& Residual & 7.448 & 347 & .021 & & \\
& Total & 9.226 & 351 & & & \\
\hline
\end{tabular}

a. Dependent Variable: NPL ratio

b. Predictors: (Constant), CORPORATE TAX, GDP \%, INFLATION \%, INTEREST RATES \%

Table 3 below shows the regression coefficients for all variables. The above table shows that the corporate tax with a significance of 0.06 shows affects the level of NPLs. Only the interest rates have an important negative impact on NPLs, indicating that with their increase of $1 \%$ level the NPLs decrease 7.358 times, with the other variables remaining constant.

Table 3: Regression coefficients and significance

Coefficients $^{\mathrm{a}}$

\begin{tabular}{|c|c|c|c|c|c|}
\hline \multirow[t]{2}{*}{ Model } & \multicolumn{2}{|c|}{ Unstandardized Coefficients } & Standardized Coefficients & \multirow{2}{*}{$t$} & \multirow{2}{*}{ Sig. } \\
\hline & $B$ & Std. Error & Beta & & \\
\hline (Constant) & .535 & .053 & & 10.024 & .000 \\
\hline GDP $\%$ & -.300 & .378 & -.047 & -.793 & .428 \\
\hline 1INFLATION \% & .020 & 1.012 & .001 & .019 & .984 \\
\hline INTEREST RATES \% & -7.358 & 1.287 & -.513 & -5.717 & .000 \\
\hline CORPORATE TAX & -.064 & .034 & -.153 & -1.910 & .057 \\
\hline
\end{tabular}

a. Dependent Variable: NPL ratio 


\section{Conclusions and Discussion}

The interesting results of our variables model and correlation show that macrovariables affect NPL ratio and as such should be taken into consideration for any analysis performed for NPL ratio. The regression model can be re-written as below:

NPLratio $=0.535-0.3 \mathrm{GDPgrowth}+0.02$ Inflationrate-7.35Interestrate-0.064Corporatetaxrae
.sig (0)
(0.984)
(0.0)
(0.057)

By the results it can be seen that the NPL ratio has a negative relationship with any of the variables except inflation rate. But not all the variables are important for changes in NPL ratio. The government policies on tax do no effect in NPL ratio in Albania for the period Q4 2008- Q4 2014 as we have initially hypothesized. The same is evident for the GDP growth and inflation rate.

While for interest rate the model is proved statistically significant being in compiance with other studies such as that of Sinkey\&Greewalt (1994) resulting the effect of interest rate on NPLs. On the other hand regarding of the effect of GDP growth, results are different with the studies of Ryan \& Dhal (2003), De Bock et al (2012) and Makri et al (2013), which proved this variable as significant. The study of Clementina et al (2014) did not reach the same results with our study regarding the inflation rates. Regarding tax policy variable as part of governmental policies, studied by Clementina et al (2014) in Nigeria resulted that unpredictable government policy had an effect on NPLs, while in Albania we did not conclude this.

In summary our model containing only macro variables is proved to explain the dependent variable of nonperforming loans, but from the macroeconomic variables only interest rates are shown to be statistically significant for our dependent variable of non-performing loans. The initial hypothesis that tax rate will affect non-performing loans has been proved statistically significant at a lower level, but the fact that there exist a positive correlation between the variables creates a field for further research. Finally the fact that in this regression were included only macroeconomic variables creates a further field of research to include also bank specific variables in the model and assess the new results.

\section{References}

Anderson"Bagehot on financial crises 1825...and 2008", Economic synopses, Federal Reserve Bank, 2009.

Baholli et al. "Analysis of Factors that Influence Non-Performing Loans with Econometric Model, Albanian Case" Mediterranean Journal of Social SciencesMCSER Publishing, Rome-Italy ,Vol 6 No 1, 2015

Bercoff, et al, "Argentinean Banks, Credit Growth and the Tequila Crisis: A Duration Analysis." (Unpublished at the reference paper), 2002.

Clementina et al, "The rising incidence of Non-performing loans and the nexus of economic performance in Nigeria: An investigation.'European Journal of Accounting Auditing and Finance Research Vol.2, No.5, pp. 87-96, July 2014 Published by European Centre for Research Training and Development UK (www.ea-journals.org), 2014.

De Bock, Reinout, et al., "Bank Asset Quality in Emerging Markets: Determinants and Spillovers." International Monetary Fund Working Paper WP/12/71, 2012

Freeman R, Bloem M, "The Treatment of Nonperforming Loans",Statistics Department, International Monetary Fund, 2005.

Hu, J., Yang, L. \& Yung-Ho, C., "Ownership and Nonperforming Loans: Evidence from Taiwan's Banks. Developing Economies" (Forthcoming at the reference paper), 2006.

Makri et al., "Determinants of Non-Performing Loans: The Case of Eurozone",Panoeconomicuspg 193-206, 2013.

Mesnard et al., "Non-performing loans in the Banking Union: stocktaking and challenges" IPOL EGOV DIRECTORATE-GENERAL FOR INTERNAL POLICIES ECONOMIC GOVERNANCE SUPPORT UNIT, 2016.

Saba et al., "Determinants of Non Performing Loans: Case of US Banking Sector", Romanian economic journal, 2012.

Shingjergji, "The Impact of Bank Specific Variables on the Non Performing Loans Ratio in the Albanian Banking System" Research Journal of Finance and Accounting www.iiste.org, Vo 4, № 7, 2013.

Saunders \& Cornett, "Financial Institutions Management" Sixth Edition, 2003.

Sinkey, J. F. \& Mary B. G., "Loan-Loss Experience and Risk- Taking Behavior at Large Commercial Banks". Journal of Financial Services Research, 5, 43-59, 1991.

Keeton, W. \& Charles, S. M., "Why Do Banks' Loan LossesDiffer?” Federal Reserve Bank of Kansas City, Economic Review, May,3-21, 1987.

Rajan, R. \&Sarat, C. D., "Non-performing Loans and Terms ofCredit of Public Sector Banks in India: An Empirical Assessment". Occasional Papers, 24(3), 81-121, 2003.

Rose et al., "An estimate of the effect of common currencies on trade and income", 2003.

Vatanseveret al.,"Determining Impacts on Non-Performing Loan Ratio in Turkey"Journal of Finance and Investment Analysis, vol. 2, no.4, 2013, 119-129 ISSN: 2241-0998 (print version), 2241-0996(online) Science press Ltd, 2013. 